\title{
Database Specification
}

National Cancer Institute

\section{Source}

National Cancer Institute. Database Specification. NCI Thesaurus. Code C115590.

A detailed description of the framework, and process required to build a database for paper and electronic data capture (EDC). 